Session 2115

\title{
Ethics and the Design Process
}

\author{
Ronald B. Meade, Ph.D, PE \\ Associate Professor, Department of Civil and Environmental Engineering \\ United States Air Force Academy
}

What we owe others is the essence of ethics. Codes of ethics make clear the principles of ethical conduct, specific obligations and prohibitions. Undergraduate education is the proper place to introduce engineering students to ethical concepts. Professions like engineering have specific duties to the public, peers, and clients.

Engineering educators can cover ethics in a stand alone fashion or spread it across the curriculum. At the United States Air Force Academy (USAFA) we in civil engineering have chosen to spread the ethics components throughout the curriculum. The purpose of this paper is to describe how ethics was introduced into a foundation design course and the benefit of this particular approach for the students.

\section{Why a design course?}

Design is about making decisions. A design course is an ideal place to discuss ethics because the design process includes many ethical decisions and practices. The students learning the design process face these decisions and use these practices although they may not recognize the ethical components. The practice of foundation design has many ethical features embedded in the procedures. Many of these features are common to all design but some are specific to foundation engineering practice. The discipline-specific features are associated with the site characterization requirements of foundation engineering.

\section{Preparing the students}

The specific discussion of ethics was not done up front. Instead, the topic was introduced as it naturally occurred in the design process. The setting for the instruction was largely role playing. The students were told at the first class meeting that they have been hired out of college into our geotechnical design firm. They were new project engineers and I was their supervisory professional engineer. The students have had a soil mechanics course as a prerequisite and were enrolled in a concrete design course during this semester. All of the students had completed basic structural engineering analysis courses and many were enrolled in a construction management elective course as well. 


\section{Business practices}

Foundation engineering is a business. The need to run a profitable business was clear to each student at the time of our first class meeting. The students did not realize what pressures would emerge from the need for profitability. I spent two class periods describing our business practices. I will briefly review the business issues as described to the students because the business aspects were essential to the ethics instruction.

Our mock firm must bill our clients and collect funds totaling a certain amount each month or we will not be able to cover our operating costs. We did an approximate calculation of our revenue needs for our firm based on a multiplier of 3 . For that specific period I assigned a position to each class member such as project engineer, laboratory supervisor, technician, drill rig operator and helper. I assigned typical salaries to each position, totaled them and multiplied by 3 to cover taxes, insurance, retirement, health benefits, and office and equipment overhead. Then the students discovered how much work in projected billings our firm must bring in each month merely to cover our expenses. The students were amazed. At this point they did not understand the difference between gross billing and net income. For example, a typical calculation may show that our firm required $\$ 1.4$ million dollars annually in collected billings just to cover our costs. If we earned only $\$ 1$ million annually we would not survive with our present workforce structure. They seemed to understand this issue during the class but later it became apparent that they did not fully comprehend the relationships among the unit cost of labor, billable hours, and the time required to complete a task when we discussed preparation of proposals.

The need to capture work, complete the project, bill the client and collect sufficient revenues is absolute. This imperative can come into conflict with ethical practice. The appropriate resolution of these conflicts is our obligation as professionals.

Our client for our mock geotechnical firm was a virtual architectural/engineering (A/E) firm. Each student provided a foundation design report for the A/E. A project engineer from the mock $\mathrm{A} / \mathrm{E}$ provided our geotechnical firm with project information and asked our firm to provide a proposal for our work. I acquainted the class with our business routine. Sometimes our firm negotiated our costs with the $\mathrm{A} / \mathrm{E}$, but often, the $\mathrm{A} / \mathrm{E}$ was soliciting proposals from several foundation design firms. In principle our proposal was treated as a bid. I informed the students that some jurisdictions forbid licensed engineers to submit bids for work.

I described the design process and we, as a class, did backward planning to prepare our proposal. That is, we visualized our design process working backwards in time from our final product, the foundation recommendations, through analysis, field/laboratory testing to site investigation. The students struggled with the preparation of a boring and sampling plan, one of our initial tasks. The preparation of a boring and sampling plan is never routine. The plan details depend on four factors: project characteristics, geological setting of the site, the subsurface information available about the site and the experience of the geotechnical engineer. The students were very uncomfortable with the process. I coached them through the entire planning process. 
When we had our proposal completed I asked them if they were comfortable with the product. They were not. I upset them further by reminding them that other competing firms were preparing proposals for this project.

"What will happen if we are not selected to perform the work? Can we recover the costs of preparing this proposal? How do you expect that the A/E will evaluate the proposals?"

The students debated these questions among themselves. The students quickly insisted that the cheapest proposal would be awarded the work. We took the opportunity to discuss qualificationbased selection. We recognized that having a low cost relative to our competitors is a good thing. I asked how we should do that. The students insisted that we cut our profit and reduce the hourly cost of design services. I asked, "How are we to make payroll if we must complete the work for less revenue than it costs us to perform the work?"

Consternation followed for the students. They seemed stumped. Then, we discussed unit costs of labor. That is, how much does it cost a firm to support an engineer or technician or driller to work for an hour? Our firm and our competitors probably paid similar salaries and have similar costs for employee benefits. So, our unit costs of work were similar to those of our competitors. So the only way to charge less is to work less. That is, work fewer hours or make fewer borings or perform fewer tests. We could not reduce our design and analysis time without reducing the value of our product, the foundation design recommendations. We may be able to produce a sound set of recommendations if we can characterize the site with fewer borings or fewer tests.

What are the minimum number of borings and tests that are needed? Is there some statutory or code requirement? Our textbook cited several building codes and offered some other advice in the form of regression relationships for typical depth of borings and number of borings per square foot of covered area. The students discussed how we might create a competitive advantage over other geotechnical firms either by performing a more thorough office study of the proposed site or by having superior knowledge of the site based on previous geotechnical experience within the local area.

\section{How much site investigation is enough?}

"How do we know that this minimum number is sufficient for us to characterize the site?" What if our site investigation missed important subsurface features or our testing revealed a confusing or ambiguous model of the site? What if we made a mistake? We discussed the concept of standard of care.

Engineers can not guarantee perfection. We make mistakes. If we make a mistake, are we negligent? We discussed the meaning of standard of care with respect to negligence. Most of the students had never discussed these topics within an engineering context. In other classes they may have discussed malpractice, negligence, and product liability. We discussed the concepts at length, but we did not yet specifically introduce the code of ethics. As a result of our class discussion the students came to believe that we must have confidence in our recommendations and the analyses that support them. The students recognized that the engineer himself is responsible for judging the adequacy of the boring and sampling plan. The students realized that if we made an error we were responsible for damages caused by our mistake. Further, the 
students realized that the charge of negligence would be determined in some type of judicial or administrative procedure where experts would be called to help the judging body determine the standard of care and whether our work conformed to the standard.

Each student submitted a site suitability report as one of his class projects. The report was drafted for my signature and his signature. I evaluated each report and insisted on changes or further work before I could agree to the recommendations. The students understood that their work would be guided and supervised by a licensed engineer who was responsible for the project. Their task was to faithfully complete the work that he had organized and guided and submit the work to the responsible engineer for his evaluation. The students seemed relieved that the supervisor was the responsible party.

An ethics question was one of several questions on the mid-semester exam. The students were presented with a realistic situation and asked what they should do. The adequacy of their answer depended on the recognition of the ethical issues and their response to those issues in light of what we have discussed so far during the course.

At this point in the course, they had prepared a boring and sampling plan, completed a site suitability report and responded to an ethics question on an exam. The students had discussed our business practices and negligence issues during class. Next, I asked the students to evaluate the ethical components of their work.

To enable the students to recognize the ethical issues in their completed work I provided the students with the American Society of Civil Engineers (ASCE) code of ethics (ASCE, 1996) as a handout together with an additional handout that was keyed to the code canons and guidelines. I also provided the ASCE policy statement on sustainable development (ASCE, 1996). The code and policy statement can be found at the ASCE web site.

\section{What they learned}

The class, armed with the ASCE code with its principles, canons, and guidelines, reviewed the work they had performed. A handout provided to the students is shown in the box on the following page. The handout was keyed to the guidelines found in the code. The students were to reflect on the work that they had performed during the course. Had we complied with the concepts of the code? The class and I also reviewed the ethics situation from the exam.

I selected nine topics on which to focus our classroom discussion. The topics were chosen based on my experience in the practice and teaching of geotechnical engineering. The choices were influenced by my experience in teaching legal aspects of engineering and experience within the military. I cannot claim any particular merit for the topics selected except that they helped to achieve my educational outcome for my students. Our cadets will be members of two professions, the profession of arms and the engineering profession. The nine questions drew parallels to the USAFA core values of integrity, service and excellence, and the USAFA honor code. The honor code states, "We will not lie, steal, or cheat nor tolerate among us anyone who does." My intent was to demonstrate to the students that the conduct expected of engineers was similar to the conduct expected of USAFA cadets. 
The handout is presented in the box exactly as it was provided to the students. The acronyms for Department of Defense (DOD), Air Force (AF) and the Occupational Safety and Health Administration (OSHA) were not provided in the handout.

\section{Civ Engr 491 Ethics}

Review the nine items and associated questions using the Code. This class exercise provides opportunities to discuss issues that are specifically mentioned in the ASCE Code of Ethics such as sustainable development, whistle-blowing, engineering standards, competence, expert witness, use of confidential information, appropriate advertising, providing proper credit for work performed, and professional development. The symbol $\mathrm{C} 1 \mathrm{~b}$ represents Canon 1 paragraph $\mathrm{b}$.

1. Sustainable development, $\mathrm{C} 1 \mathrm{c}, \mathrm{C} 1 \mathrm{e}, \mathrm{C} 1 \mathrm{f}, \mathrm{C} 3 \mathrm{a},---$ What is DOD and AF policy on sustainable development? How do the four pillars of environmental policy apply?

In November 1996, the ASCE Board of Direction adopted the following definition of Sustainable Development: "Sustainable Development is the challenge of meeting human needs for natural resources, industrial products, energy, food, transportation, shelter, and effective waste management while conserving and protecting environmental quality and the natural resource base essential for future development."

2. whistle-blowing, $\mathrm{C} 1 \mathrm{~d}, \mathrm{C} 4 \mathrm{~d}, \mathrm{C} 5 \mathrm{~g}$ - How does the code guidance compare to condonation and toleration as taught in honor education at USAFA

3. engineering standards, $\mathrm{C} 1 \mathrm{~b}$ - What standards? How does "standard of care" apply?

4. competence, $\mathrm{C} 2 \mathrm{~b}, \mathrm{C} 2 \mathrm{c}, \mathrm{C} 3 \mathrm{c}, \mathrm{C} 5 \mathrm{~b}$ - Who decides if you are competent? How do you decide if someone else is competent? For OSHA what is a competent person?

5. expert witness, $\mathrm{C} 3 \mathrm{c}-$ What is an expert witness? Who decides the witness is expert? Could you become an expert witness?

6. use of confidential information, $\mathrm{C} 3 \mathrm{~b}, \mathrm{C} 4 \mathrm{f}-$ Who judges what is confidential? We are NOT talking about security classification.

7. appropriate advertising, $\mathrm{C} 5 \mathrm{f}-$ Look at your cover letter to the client in your site suitability report. Is your language appropriate? How do some cadets violate these standards when giving briefings?

8. providing proper credit for work performed, $\mathrm{C} 5 \mathrm{e}$-- Compare this requirement to documentation standards at USAFA.

9. professional development. C7 - How does this canon provide guidance to leaders? Compare lifelong learning in this code to the Dean's outcomes? Have you participated in ASCE student functions? 
The students addressed the nine questions shown on the handout during one 50-minute period of classroom discussion. No formal assessment of the engineering ethics was planned. The ethics instruction was an initial attempt to formally devote several class periods to ethics. I have recorded the student feedback to each of these questions very briefly as a qualitative assessment of the instruction.

\section{$\underline{\text { Sustainable development }}$}

Four references to sustainable development occur in the code. Three of these are within the guidelines of the $1^{\text {st }}$ canon. Twice the guidelines refer to the "principles of sustainable development," once to the practice of sustainable development and once to duty to extend knowledge of sustainable development in the guideline to the $4^{\text {th }}$ canon. Sustainable development is a new topic for the students. I handed out a copy of the ASCE policy 418 (ASCE 1996) on sustainable development for our discussion. The ASCE policy statements are available at the ASCE web site. We did little in our discussion with this topic. My purpose was to make the students aware of our professional duty to consider sustainable development.

\section{Whistle-blowing}

The academy has an honor code and each cadet has about 40 hours of honor education during their 4-year program. We discussed toleration and condonation with respect to the academy and the engineering profession. Toleration at the academy refers to the obligation of each cadet to report violations of the honor code. Condonation refers to the non-reporting of violations of regulations other than honor. Each cadet swears that he or she will report all violations of the honor code. No such mandate is sworn regarding reporting violations of other regulations. We discussed the engineer's duty to protect the public. The cadets were advised that whistleblowing to protect the public is an obligation. We noted that whistle-blowers almost always suffer personally and professionally for their courage to do their duty. We also stressed the obligation to speak the truth to ensure that we do not unjustly impugn or damage the reputation of other engineers or the engineering profession. The students seemed comfortable in acknowledging these responsibilities.

\section{$\underline{\text { Engineering standards }}$}

We discussed the standard of care concept again. The students were comfortable with this idea. We also discussed consensus standards and noted that consensus standards can either be adopted as a regulatory standard or adopted by parties within a contract as a contract provision. The students were quick to mention the steel and concrete design codes.

\section{Competence}

Who decides if I am competent to practice? We discussed licensure and the general title of registered professional engineer. We talked about specialty certification and the need to be qualified by some combination of education and experience to perform specific engineering tasks. The students readily accepted that the licensed engineer must practice only in area in which he or she is competent. 


\section{$\underline{\text { Expert witness }}$}

My students may well serve as expert witnesses some day. We discussed how the court determines that an expert is, in fact, expert. They recognized that the expert plays a large role in defining the standard of care for a judge or jury. The students expressed interest in learning more about how such legal proceedings work through their questions.

\section{$\underline{\text { Use of confidential information }}$}

I clarified for my cadets that we were not talking security classification, but instead private information. The task of judging what information is confidential can be difficult. We did not explore this issue beyond noting that some information is protected intellectual property while other confidential information is sensitive because of privacy concerns.

\section{Appropriate advertising}

The students had a difficult time with this concept. The cadets are very competitive and prone to brag, boast and intimidate their peers. They had difficulty with the concept "the dignity of the profession." They saw nothing wrong with unabashed unsupported statements that they were better than their competition.

\section{Providing credit for work of others}

The students were clear that you cannot take credit for the work of others. In addition you must credit the work of others when you use it or expand on it. The students were accustomed to carefully documenting their work.

\section{$\underline{\text { Professional development }}$}

Life-long learning is stressed as an educational outcome at USAFA and in the engineering profession. The students readily accepted that professional development is a requirement for engineering practice. We observed that our professional society ASCE was a sponsor and source of professional development materials. We discussed our obligation to support our professional society with contributions of both time and money. I asked them to discuss their support of our student chapter of ASCE.

\section{Next time}

I plan to continue this exercise in both of the geotechnical design electives that we offer. It was helpful to me as well as to my students to be able to share expectations about ethical issues. The students expressed thanks at having discussed these issues. They seemed to be more comfortable with their choice of engineering as a field of study and proud of engineering as a profession. I believe that placing the ethics instruction after completion of some design work was beneficial. The students could recall their emotions and concerns as they made design decisions in light of the ASCE ethics guidance. It was clear from the student discussions that the students saw that 
Air Force corps values of integrity, service before self, and excellence had parallels in the ASCE code of ethics.

A more formal assessment of the ethics instruction will be incorporated into future course offerings. During the fall 2003 offering I made my informal assessment based on the response of the students to the mid-term exam question, an ethics question that was included in an end-ofcourse exam, and the student classroom discussion.

I intend to devote more time to the topics of sustainable development and appropriate professional advertising in the fall 2004 offering. Each of these topics can be addressed through examples found at sites on the World Wide Web. The ethics instruction will be evaluated by means of a short paper. The students will be required to present examples of concerns that are applicable to selected canons of the ASCE code of ethics.

\section{BIBLIOGRAPHIC INFORMATION}

American Society of Civil Engineers. 1996. Code of Ethics [on line], [cited 12 Mar 2004] Available from the World Wide Web: <https://www.asce.org/inside/codeofethics.>

American Society of Civil Engineers. 2001. The Role of the Civil Engineer in Sustainable Development Policy Statement 418 [on line], [cited 12 Mar 2004] Available from the World Wide Web: <

https://www.asce.org/pressroom/news/policy_details.cfm>

\section{BIOGRAPHICAL INFORMATION}

Dr. Ronald B. Meade is a faculty member at the USAF Academy (1998 - present). He is a registered professional engineer in Indiana and formerly taught at the Virginia Military Institute (1984-1992). 